\title{
Assessment of essential and nonessential dietary exposure to trace elements from homegrown foodstuffs in a polluted area in Makedonska Kamenica and the Kočani region (FYRM)
}

\author{
Petra Vrhovnik $^{\mathrm{a}, *}$, Matej Dolenec ${ }^{\mathrm{b}}$, Todor Serafimovski ${ }^{\mathrm{c}}$, Goran Tasev ${ }^{\mathrm{c}}$, Juan P. Arrebola ${ }^{\mathrm{d}}$ \\ a GEOEXP d.o.o., Slap 21, SI-4290 Trzic, Slovenia \\ ${ }^{\mathrm{b}}$ University of Ljubljana, Faculty of Natural Sciences and Engineering, Department of Geology, Aškerčeva 12, SI-1000 Ljubljana, Slovenia \\ c Faculty of Mining, Geology and Polytechnics, University "Goce Delcev - Stip", Goce Delcev 89, 2000 Stip, Macedonia \\ ' Instituto de Investigación Biosanitaria ibs. GRANADA, Hospitales Universitarios de Granada, University of Granada, CIBERESP, 18071 Granada, Spain
}

\section{H I G H L I G H T S}

- The study merges the accumulation of ETE and NETE in home-grown foodstuffs.

- Considerably high health risks for inhabitants

- Correlation between pollution and human health

\section{A R T I C L E I N F O}

\section{Article history:}

Received 10 November 2015

Received in revised form 28 March 2016

Accepted 28 March 2016

Available online $\mathrm{xxxx}$

Editor: D. Barcelo

\section{Keywords:}

Essential trace elements

Nonessential trace elements

Edible foodstuffs

FYR Macedonia

Daily/weekly intake

\begin{abstract}
A B S T R A C T
The main purpose of the present study is to assess human dietary exposure to essential and non-essential trace elements via consumption of selected homegrown foodstuffs. Twelve essential and non-essential trace elements ( $\mathrm{Cd}, \mathrm{Co}, \mathrm{Cu}, \mathrm{Cr}, \mathrm{Hg}$, Mo, Ni, Pb, Sb, Se, $\mathrm{Zn}$ and $\mathrm{As}$ ) were detected in various homegrown foodstuffs. Detailed questionnaires were also applied among a sample of the local population to collect information on sociodemographic characteristics. The results of the present study clearly indicate that the majority of the trace elements are at highly elevated levels in the studied foodstuffs, in comparison to international recommendations. The maximum measured levels of ETE and NETE are as follows [ $\mu \mathrm{g} \mathrm{kg}{ }^{-1}$ ]: Cd 873, Co 1370, Cu 21700, Cr 59633, Hg 26, Mo 6460, Ni14.5, Pb 11100, Sb 181, Se 0.30, Zn 102 and As 693. Additionally, age, body mass index and gender were significantly associated with levels of dietary exposure. Further research is warranted on the potential health implication of this exposure.

Capsule abstract: The study merges the accumulation of ETE and NETE in home-grown foodstuffs and reflects considerably high health risks for inhabitants.
\end{abstract}

(c) 2016 Elsevier B.V. All rights reserved.

\section{Introduction}

Vegetables are important components of the human diet, as rich sources of vitamins, minerals, fibre as well as their beneficial antioxidant effects (Ali and Al-Qahtani, 2012). The uptake and bioaccumulation of metals and metalloids in plant species are influenced by a number of different factors such as climate, atmospheric depositions, background geology and soil composition, the vicinity of roads and industry, as well as the degree of maturity of the plants at the time of harvest (Lake et al., 1984; Votusa et al., 1996). Certain trace

\footnotetext{
* Corresponding author.

E-mail address: petra.vrhovnik@gmail.com (P. Vrhovnik).
}

elements have known long half-lives and the majority are not easily biodegradable, so when they accumulate in different parts of the body, where they can remain for long periods and exert harmful effects, especially at certain critical stages of life, such as pregnancy or childhood (Swaddiwudhipong et al., 2014; Hu et al., 2015; Thomas et al., 2015). This might probably be a result of the lack of proper mechanisms for their removal from the body (Amin et al., 2013).

Even though some trace elements are essential for normal body function, they can be extremely toxic in high concentrations. The consumption of vegetables rich in trace elements can cause various clinical and physiological conditions in all living organisms; for example, exposure to high doses of trace elements like $\mathrm{Pb}, \mathrm{Cd}$ and $\mathrm{Cu}$ is related to an increased prevalence of upper gastrointestinal cancer (Turkdogan et al., 2002). Furthermore, all trace elements (essential or nonessential) 
at exceedingly high concentrations can have adverse effects on human health, as well as on animal and plant health. In addition, this issue becomes even more complex if we take into account that humans are typically exposed to complex mixtures of trace elements and other pollutants on a daily basis, which can even produce biological effects at concentrations that would have negligible effects on their own (Orton et al., 2013).

The nature of soils and consequently of the background geology are the most important factors in determining the content of trace elements in foodstuffs (Itanna, 2002; Madyiwa et al., 2002). While the present research area is the metal-rich region in the Osogovo Mountains in Eastern FYR Macedonia, the concentrations of trace elements in surrounding soils are expected to be enriched. The two main regions discussed in this paper are the Makedonska Kamenica region and Kočani agricultural valley, and both are irrigated with water from Lake Kalimanci. According to Mapanda et al. (2005) and Chung et al. (2011), irrigation with contaminated water may not only result in soil contamination but also affect food quality and safety for end-users. The aforementioned accumulation reservoir (Lake Kalimanci) is being supplied with water from River Kamenica which flows beneath the Sasa tailings dam. This dam stores waste material and waste waters from the nearby lead-zinc Sasa mine. Ten years ago, the aforementioned Sasa tailings dam collapsed and caused an intensive flow of waste material all the way through Kamenica river valley that was deposited in Lake Kalimanci. An evaluation of Lake Kalimanci's contamination status was published in our earlier papers (Vrhovnik et al., 2013ad). In summary, the applied enrichment factor (EF) and index of geoaccumulation $\left(\mathrm{I}_{\mathrm{geo}}\right)$ showed that the most crucial trace elements in surficial Lake Kalimanci sediments are Pb, Zn, Cd, Bi and Ag. Meanwhile the sequential extraction procedure revealed that $\mathrm{Cu}, \mathrm{Pb}, \mathrm{Zn}, \mathrm{Ni}, \mathrm{Cd}, \mathrm{Bi}$ and $\mathrm{Hg}$, as well as $\mathrm{Co}$ and $\mathrm{Sb}$, are highly mobile in the exchangeable fraction, which undoubtedly represents an increased environmental risk. This means that the lake's surficial sediments comprise a great number of potentially toxic trace elements which are easily available to nearby living species, and which thus present a great threat to the inhabitants. On the other hand, Lake Kalimanci water was found to be strongly contaminated with $\mathrm{Pb}, \mathrm{Cd}$ and $\mathrm{Se}$, while other trace elements seem not to have such alarming values. However, it is important to note that when lake water is compared to waters from the Sasa Mine, an interesting pattern is noticed. All the trace elements were expected to be higher in the Sasa Mine waters, but the results revealed that $\mathrm{Cr}, \mathrm{As}, \mathrm{Ag}$ and Se had higher values in the lake water. Furthermore, according to Dolenec et al. (2007), very high concentrations of $\mathrm{Ag}, \mathrm{As}, \mathrm{Cd}, \mathrm{Cu}, \mathrm{Mo}, \mathrm{Ni}, \mathrm{Pb}, \mathrm{Sb}$ and $\mathrm{Zn}$ were found in the paddy soil samples in the vicinity of the Zletovska River (western part of Kočani Field).

According to Horvath and Gruiz (1996), lead/zinc mining and smelting activities are some of the primary sources of trace element pollution in the environment. From the 18th to the 20th century, industrialization and intensive mining in Europe and elsewhere caused serious environmental pollution. This consequently forced governments and other environmental agencies to establish regulations specifying maximum allowable contents of pollutants such as trace elements in different media, especially in foodstuffs. This study is very important because the FYR Macedonia has not set up any legislation to control the expansion of trace elements in foodstuffs or other media (soil, water, etc.). In addition, according to El Sebae (1993), people living in developing countries are at special risk of toxic exposure mainly due to inadequate regulations and a lack of trained personnel or equipment.

The objective of the present study is (1) to quantify the levels of essential trace elements (ETE) as well as non-essential trace elements (NETE): $\mathrm{Cd}, \mathrm{Co}, \mathrm{Cu}, \mathrm{Cr}, \mathrm{Hg}, \mathrm{Mo}, \mathrm{Ni}, \mathrm{Pb}, \mathrm{Sb}, \mathrm{Se}, \mathrm{Zn}$ and As in selected edible crops from a highly polluted area in FYR Macedonia, (2) to evaluate a bioaccumulation of ETE and NETE in edible crops from the environment (soil and water), (3) to estimate the dietary exposure levels in a sample of population of this region using a previously-validated trace element pollution index, and (4) to assess the influence of some sociodemographic predictors on the estimated exposure.

\section{Materials \& methods}

\subsection{Study area and geological setting}

The Former Yugoslav Republic of Macedonia (FYRM) lies in south-eastern Europe (between $41^{\circ} 36^{\prime} \mathrm{N}$ and 21.7' $\mathrm{E}$ ) and covers $25,713 \mathrm{~km}^{2}$ of the European surface (Fig. 1a). The FYRM borders Serbia to the north, Bulgaria to the east, Greece to the south and Albania to the west. The city of Makedonska Kamenica is located approximately $12 \mathrm{~km}$ south of the $\mathrm{Pb}-\mathrm{Zn}$ Sasa mine in the Osogovo Mountain chain. Approximately 5000 people live in the city centre and another 3000 in the surrounding villages. The domestic sewage system in this area is still not well developed, and therefore many households located directly along the lakeside release waste waters into Lake Kalimanci. Meanwhile, Kočani valley lies at the foot of the Osogovo Mountains and is approximately $30 \mathrm{~km}$ south-east from Makedonska Kamenica. The Kočani valley spreads over an area of around $20 \mathrm{~km}^{2}$ and has around 28,000 inhabitants.

In Osogovo Mountains there are two main ore deposits: SasaToranica and Zletovo, which are connected by the same geology catchment. Important $\mathrm{Pb}$ and $\mathrm{Zn}$ deposits were formed, always accompanied by variable amounts of $\mathrm{Cu}, \mathrm{Au}, \mathrm{Ag}$, Mo and Sb (Vrhovnik et al., 2013b). The ore in the studied area can be found in quartz-muscovitegraphitic schists and also in greenschists and marbles (Vrhovnik et al., 2013b).

Samples of home-grown foodstuffs were taken from a wide area around Makedonska Kamenica city and from Kočani valley in early November 2013. The names of the cities/villages where samples were obtained are the following: Ćiflik, Sazlak, Podlog, Spančevo, Obleševo, Trkanje, Sasa, Sasa 1, Sasa 2, Orizari, Sokolarci, Kočani and Makedonska Kamenica (Fig. 1b). In each place several gardens were selected to form a composite pattern. Afterwards, the same foodstuff species were taken from all the selected gardens and used for further analysis as a composite sample. The selection of the foodstuffs was based on an initial survey in the local markets, where the most commonly consumed crops in the region were identified. Based on three different markets, we decided which products were most commonly on sale and could be still available in local gardens. Finally, the following foodstuffs were collected: cabbage, leek, pepper, hot pepper, carrot, lettuce, tomato, onion, wheat, parsley, quince, maize, black maize, pumpkin seed, poppy seed, propolis and pollen.

\subsection{Study population and questionnaire data}

The population study took place in the two municipalities of Kočani and Makedonska Kamenica, which together cover about $24 \mathrm{~km}^{2}$ of Macedonian territory. Both municipalities are located near several $\mathrm{Pb}-\mathrm{Zn}$ ore deposits. We included inhabitants of all ages, living all the way from the city of Kočani through the agricultural areas up to the Bregalnica River, Lake Kalimanci and Kamenica River, and to the Osogovo Mountains where the biggest $\mathrm{Pb}-\mathrm{Zn}$ active mine is located.

The study population was randomly recruited in 2012 from the adult population living in the study area. Out of 180 subjects who were contacted, 87 (48\%) agreed to participate, 23 of whom were excluded from the analysis and therefore 64 were finally used. The main reported causes of rejection included: being afraid of losing their job (35\%), feeling that the questions were too personal (15\%), and not having enough time to complete the interview (2\%).

Information on possible predictors of trace element exposure was derived from an ad hoc questionnaire completed by each participant during a personal interview, which was conducted by four trained interviewers at the time of recruitment. 


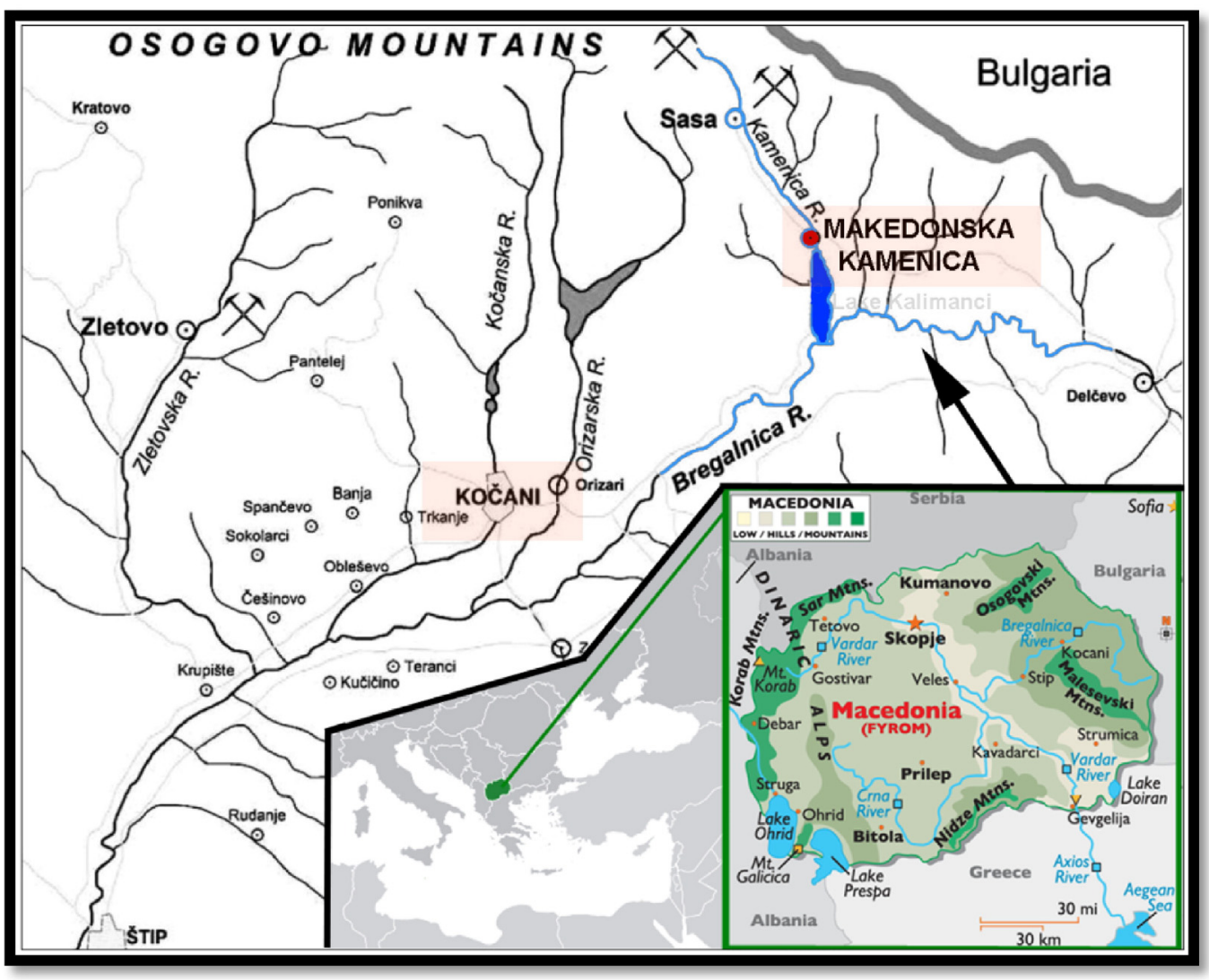

a) Geographical setting of studied area.

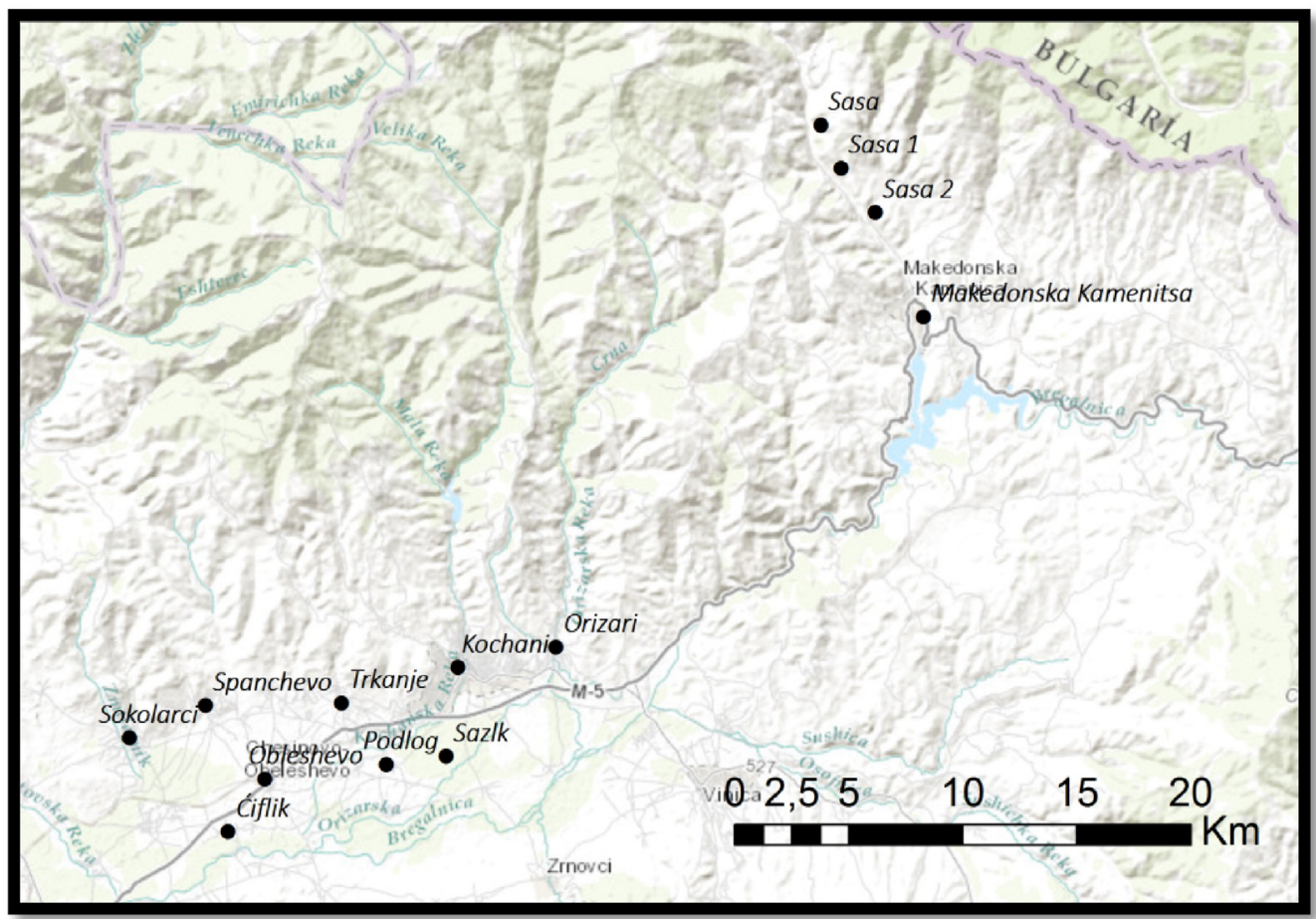

b) Topographic map of study area with marked sampling sites.

Fig. 1. a. Geographical setting of studied area. b. Topographic map of study area with marked sampling sites.

Socio-demographic characteristics included information on sex, age, body weight, residence, occupation and diet. Subjects were classified into four occupational categories: farmers, other manual workers, students and unemployed. Consumption of different foodstuffs (e.g. vegetables, fruits) was gathered as the number of portions consumed per week. 


\subsection{Chemical analyses}

All foodstuffs were washed with tap water just as the inhabitants do before consumption. This procedure lessens the trace element concentrations in foodstuffs, because it removes those which were deposited from dust. The only crop that was not washed was propolis, because it was collected from the locals and it was ready to use.

All samples were analysed for the following elements: $\mathrm{Cd}, \mathrm{Co}, \mathrm{Cu}, \mathrm{Cr}$, $\mathrm{Hg}$, Mo, Ni, Pb, Sb, Se, Zn and As, at an accredited commercial laboratory, ActLabs (Activation Laboratories Ltd., Ancaster, Ontario, Canada), using inductively coupled plasma mass spectrometry (ICP/MS) and microwave digestion. Dry, unwashed samples were digested in Aqua Regia solution $3 / 1(\mathrm{v} / \mathrm{v})\left(\mathrm{HNO}_{3}+3 \mathrm{HCl}\right)$ at $95^{\circ} \mathrm{C}$ for $2 \mathrm{~h}$. The resultant sample solutions were then diluted and analysed on a Finnegan Mat Element 2 High Resolution ICP/MS (HR-ICP/MS). The quality of the analysis was monitored by comparison with the standard materials NIST 1575a, NIST 1643e and SLRS-5 provided by ActLabs, and the measurements of four samples were repeated. Results of element concentrations in the studied samples refer to $\mathrm{kg}$ of sample. The results indicated a good agreement between the certified and observed values. For reaching the best control, measurements were repeated on 6 different samples and three standards (MP-STD-011, IAEA-407, DORM-3) using X-ray fluorescence (XRF) and inductively coupled plasma atomic emission spectroscopy (ICP-AES). The standard deviations of the means observed for the above-mentioned certified materials were between 1-5\%.

All other data used for interpretation (trace element content in sediment, soil and water) were collected from our previous researches (Vrhovnik et al., 2013a, 2013b, 2013c, 2013d; Dolenec et al., 2007).

\subsection{Estimated daily/weekly intake (EDI/EWI) E' health risk index (HRI)}

The WHO (1996) recommendations include the need to eat either at least five portions of fruit and vegetables a day, or $400 \mathrm{~g}$ of fruit and vegetables a day, and it is often assumed that a standard portion weighs about $80 \mathrm{~g}$. According to the applied questionnaire, inhabitants consume at least 2 portions of vegetables or fruits per day. For the calculation of EDI/EWI, the direct data of portion size and body weight were used from questionnaires for each person.

EDI was calculated as described by Oyoo-Okoth et al. (2010): EDI = $\left(\mathbf{C}_{\mathbf{H M}} * \mathbf{W}_{\text {vege }}\right) / \mathbf{B}_{\mathbf{w}}[\mathrm{mg}]$.

HRI was calculated by using EDI and Reference Oral Dose $\left(R_{\mathrm{f}} \mathrm{D}\right)$ adopted by USEPA (2002), with the following equation: HRI = EDI / $\mathbf{R}_{\mathbf{f}} \mathbf{D}$.

Total EDI was calculated as the sum of individual EDI values for each trace element.

\subsection{Statistical analyses}

Descriptions of the study variables were performed using means, standard deviations and percentiles (quantitative variables), and frequencies (categorical variables).

Associations between socio-demographic variables and EDI values were assessed by using multivariable linear regression models. We created one model for each EDI, in which the variables age (years), sex (male/female), ethnic group (Macedonian/other), occupation (farmer/ industry or mining/other), and BMI $\left(\mathrm{kg} / \mathrm{m}^{2}\right)$ were all entered.

Diagnosis of the models was performed in order to ensure the goodness of fit and the fulfilment of implementation conditions. Generalized standard-error inflation factors were used to verify the absence of collinearity between independent variables, while homoscedasticity was tested by plotting residual against fitted values. The linearity of quantitative independent variables was checked with partial regression plots, and the normality of errors was verified by normal QQ plots with 95\% confidence intervals (Fox, 2008).

The significance level was set at $p \leq 0.05$. Data were stored in a database managed by SPSS v20.0 (SPSS, Chicago, IL, USA).

\section{Results and discussion}

\subsection{Population characteristics}

According to the CIA (Central Intelligence Agency, 2001), the unemployment rate in FYR Macedonia in 2011 was 31.4\%, of which 55\% were between 15 and 24 years old; in addition, in 2010, approximately $31 \%$ of the population in FYR Macedonia were below the poverty line, which may also be one of the main reasons for having the same diet every day. The living status of inhabitants is presumably low; therefore, their major sources of food are either caught in nearby waters (e.g. fish) or grown in their gardens, where they use water from Lake Kalimanci for irrigation. The Macedonian Public Health Institution Skopje (Simovska-Jarevska et al., 2012) applied a general questionnaire about dietary habits, where only a brief presentation about the Macedonian diet is presented, such as (1) $82 \%$ regularly or occasionally consumed vegetables, (2) $82 \%$ of respondents regularly consumed milk and/or yogurt, (3) 19\% of all consumed fish in accordance with recommendations, (4) $96 \%$ of the population consume bread every day, etc. According to the Macedonian Public Health Institution Skopje (Simovska-Jarevska et al., 2012) the presence of non-communicable diseases (NCD) mortality was 75\%, while cardiovascular disease morbidity amounted to $57 \%$ of the total morbidity.

While the aforementioned data are brief and do not present a detailed picture of our study area, we applied a detailed questionnaire among inhabitants from the researched area, between the two towns of Makedonska Kamenica and Kočani and all the way to Sasa village, near to the Sasa mine.

The main characteristics of the study population and dietary habits are summarized in Table 1 . The population was predominantly male (64\%) and Macedonian (90.9\%). The median age was 39.5 years and the median BMI was borderline between normal weights and obese, according to the WHO recommendations (Table 1 ). The age range among the questioned inhabitants was from 20 to 76 years. All of the

Table 1

Characteristics of the study population.

\begin{tabular}{|c|c|c|c|c|c|}
\hline & \multicolumn{4}{|c|}{$\mathrm{n}$} & $\%$ \\
\hline \multicolumn{6}{|l|}{ Sex } \\
\hline Male & & 41 & & & 64.1 \\
\hline Female & & 23 & & & 35.9 \\
\hline \multicolumn{6}{|l|}{ Ethnic group } \\
\hline Macedonian & & 60 & & & 90.9 \\
\hline Others & & 6 & & & 9.1 \\
\hline \multicolumn{6}{|l|}{ Occupation } \\
\hline Unemployed & & 16 & & & 24.2 \\
\hline Industry/mining & & 13 & & & 19.7 \\
\hline School teacher & & 10 & & & 15.2 \\
\hline Farmer & & 16 & & & 24.2 \\
\hline \multirow[t]{3}{*}{ Others } & & 11 & & & 16.7 \\
\hline & \multirow[b]{2}{*}{ Mean } & \multirow[b]{2}{*}{ Standard deviation } & \multicolumn{3}{|c|}{ Percentiles } \\
\hline & & & 25 th & 50th & 75th \\
\hline Age (years) & 40.6 & 16.6 & 25.0 & 39.5 & 54.0 \\
\hline Body mass index $\left(\mathrm{Kg} / \mathrm{m}^{2}\right)$ & 24.7 & 4.0 & 21.5 & 24.8 & 27.1 \\
\hline Fish consumption & 1.6 & 0.9 & 1.0 & 1.0 & 2.0 \\
\hline Legumes consumption & 1.8 & 1.3 & 1.0 & 1.0 & 2.0 \\
\hline Rice consumption & 2.6 & 1.5 & 2.0 & 2.0 & 3.0 \\
\hline Potato consumption & 3.2 & 1.4 & 2.0 & 3.0 & 4.0 \\
\hline Tomato consumption & 6.3 & 1.6 & 7.0 & 7.0 & 7.0 \\
\hline Pepper consumption & 5.8 & 1.9 & 5.0 & 7.0 & 7.0 \\
\hline Onion consumption & 5.7 & 2.0 & 4.0 & 7.0 & 7.0 \\
\hline Salad consumption & 3.0 & 1.2 & 2.0 & 3.0 & 4.0 \\
\hline Cabbage consumption & 3.3 & 1.4 & 2.0 & 3.0 & 4.0 \\
\hline Egg consumption & 3.8 & 1.8 & 3.0 & 3.0 & 5.0 \\
\hline Fruit consumption & 6.3 & 1.4 & 7.0 & 7.0 & 7.0 \\
\hline Bread consumption & 6.8 & 0.7 & 7.0 & 7.0 & 7.0 \\
\hline pasta consumption & 2.4 & 1.4 & 1.0 & 2.0 & 3.0 \\
\hline
\end{tabular}

Food consumption was measured as portions / week. 
respondents lived near an agricultural area $(<5 \mathrm{~km})$ and near industry $(<5 \mathrm{~km})$. The majority of males (all ages) worked in the mining industry, the rest and females were either farmers or unemployed. Young people who stayed home helped their parents, while others moved to the capital to study. $47 \%$ of all questioned inhabitants smoke $>20$ cigarettes per day, and almost half of the questioned adults consume alcohol (spirits, beer or wine) every day. $91 \%$ of inhabitants in the research area drink well water or tap water and $9 \%$ buy bottled water. Among dairy products, inhabitants consume 5 to 7 times per week home-produced milk (42\%), yogurt (53\%) and homemade young cheese (44\%). Meat products (chicken, pork, beef, goat, sheep) are consumed 5 to 7 times per week (44\%), while fish is included in the diet up to 2 times per week (80\%). According to the locals, fish and frogs are caught in nearby lakes or rivers. Some locals also revealed that they also consumed frozen (cod fish) or canned fish.

\subsection{ETE and NETE levels in home grown products}

Concentrations of ETE and NETE in the edible crops are presented in Table 2, together with existing regulations from different countries. Each value corresponds to the average for the selected species from different localities. In FYR Macedonia the authorities have not yet established any such regulations or safe limits for food despite the rich metal industry in the country. As FYR Macedonia geographically belongs to Europe, we compare the measured values with those settled by the European Union Commission (EC, 2001) but only a few trace elements are included, so other regulations were considered here. Furthermore, the determined concentrations in vegetables from the present study were compared to some of the concentrations in vegetables from some other localities worldwide (Alam et al., 2003; Xilong et al., 2005; Nabulo et al., 2010; Ramirez-Andreotta et al., 2013; Ning et al., 2015), and they are much higher compared to those. Thus, the present study is of great importance for the health of local inhabitants.

According to the evaluated concentrations of the studied trace elements in different foodstuffs, it can be assumed that the majority of trace elements are present in high concentrations in comparison to the current international recommendations. If these values are compared with the allowable limits adopted by different organisations, there are five elements among the majority samples that greatly exceed the safe limits; these are $\mathrm{Cd}, \mathrm{Co}, \mathrm{Cu}, \mathrm{Pb}$ and $\mathrm{Zn}$ (Table 2, bolded). These are closely followed by $\mathrm{Cr}$ and As. Meanwhile, others ( $\mathrm{Hg}, \mathrm{Mo}, \mathrm{Ni}, \mathrm{Sb}$ and Se) either do not exceed the safe limits or still do not have established upper allowable levels.

$\mathrm{Cd}$ has the highest detected concentration measured in tomato (873 $\left.\mu \mathrm{g} \mathrm{kg}^{-1}\right)$, closely followed by onion $\left(816 \mu \mathrm{g} \mathrm{kg}{ }^{-1}\right)$, carrot (557 $\mu \mathrm{g} \mathrm{kg}^{-1}$ ) and leek $\left(500 \mu \mathrm{gg}^{-1}\right)$. The measured Cd exceeded the maximum allowable limits also in the majority of other samples, such as (hot) pepper, lettuce, parsley, quince, pumpkin and poppy seed, propolis and pollen. Co was well above the allowable limits in all samples, with the highest values detected in lettuce $\left(1370 \mu \mathrm{g} \mathrm{kg}^{-1}\right)$. Much the same is with $\mathrm{Cu}$, which also exceeds the recommended concentrations in all samples, with maximum values in pumpkin $\left(21,700 \mu \mathrm{kg}^{-1}\right)$ and poppy $\left(20,900 \mu \mathrm{gg}^{-1}\right)$ seeds. Pb was detected from very high contents to very low concentrations in the studied samples. Propolis has the highest content of $\mathrm{Pb}\left(11,100 \mu \mathrm{g} \mathrm{kg}^{-1}\right)$, while other foodstuffs have measured values from $10 \mu \mathrm{g} \mathrm{kg}^{-1}$ in black maize, $1833 \mu \mathrm{g} \mathrm{kg}{ }^{-1}$ in lettuce, $1437 \mu \mathrm{g} \mathrm{kg}{ }^{-1}$ in leek, and up to $3310 \mu \mathrm{g} \mathrm{kg}^{-1}$ in quince. $\mathrm{Zn}$ is well known as an essential element for normal human function, but it can also become poisonous, when its intake is on a daily basis and exceeds recommended safe limits. The upper allowable level for $\mathrm{Zn}$ is $0.2 \mathrm{mg} \mathrm{kg}^{-1}$ and this limit was exceeded among all the studied samples. The highest concentration of $\mathrm{Zn}$ was detected in propolis (102 $\mathrm{mg} \mathrm{kg}^{-1}$ ), closely followed by poppy and pumpkin seeds, onion, parsley, lettuce and others. Lettuce samples contained $59,633 \mu \mathrm{g} \mathrm{kg}^{-1}$ of $\mathrm{Cr}$, and also pumpkin seed, parsley, quince and leek comprise over $10,000 \mu \mathrm{gg}^{-1}$ of $\mathrm{Cr}$, which is over safe limits. As also exceeds allowable upper limits in three sample groups, with its maximum concentration detected in lettuce $\left(693 \mu \mathrm{gg}^{-1}\right)$ followed by parsley ( $\left.529 \mu \mathrm{gg}^{-1}\right)$ and leek $\left(440 \mu \mathrm{gg}^{-1}\right)$.

Our results confirmed that all the edible crops analysed showed a detectable concentration of at least one of the studied chemicals. However, despite global pollution, there was no unique main dietary source of exposure for ETEs and NETEs, since the main sources of exposure of each chemical were different.

\subsection{Transfer Factor (TF) relation vegetable to water/soil}

To evaluate the accumulation of ETE and NETE in edible crops in relation with water and soils the transfer factor (TF) was calculated

Table 2

The measured contents of ETE and NETE in edible crops.

\begin{tabular}{|c|c|c|c|c|c|c|c|c|c|c|c|c|}
\hline Mean & $\mathrm{Cd}$ & Co & $\mathrm{Cu}$ & $\mathrm{Cr}$ & $\mathrm{Hg}$ & Mo & $\mathrm{Ni}$ & $\mathrm{Pb}$ & $\mathrm{Sb}$ & Se & $\mathrm{Zn}$ & As \\
\hline DL & 0.1 & 0.5 & 20 & 10 & 5 & 1 & 0.1 & 10 & 0.2 & 0.2 & 0.2 & 5 \\
\hline Unit & $\mu \mathrm{g} \mathrm{kg}^{-1}$ & $\mu \mathrm{g} \mathrm{kg}^{-1}$ & $\mu \mathrm{g} \mathrm{kg}^{-1}$ & $\mu \mathrm{g} \mathrm{kg}^{-1}$ & $\mu \mathrm{g} \mathrm{kg}^{-1}$ & $\mu \mathrm{g} \mathrm{kg}^{-1}$ & $\mu \mathrm{g} \mathrm{kg}^{-1}$ & $\mu \mathrm{g} \mathrm{kg}^{-1}$ & $\mu \mathrm{g} \mathrm{kg}^{-1}$ & $\mu \mathrm{g} \mathrm{kg}^{-1}$ & $\mu \mathrm{g} \mathrm{kg}^{-1}$ & $\mu \mathrm{g} \mathrm{kg}^{-1}$ \\
\hline Cabbage (leaf) & 43.2 & 138 & 2450 & 1140 & 11.5 & 885 & 1100 & 255 & 10.9 & 202 & 23,500 & 53.5 \\
\hline Leek & 500 & 473 & 5980 & 13,080 & 12.3 & 823 & 4700 & 1437 & 23.0 & 140 & 46,400 & 440 \\
\hline Pepper & 200 & 193 & 10,380 & 1432 & 4.03 & 415 & 1220 & 192 & 12.5 & 140 & 28,200 & 70.2 \\
\hline Hot pepper & 208 & 49.2 & 7260 & 1330 & $3.54^{\mathrm{a}}$ & 41.0 & 1000 & 650 & 12.2 & 140 & 42,100 & 15.0 \\
\hline Carrot (root) & 557 & 190 & 9430 & 4070 & 11.0 & 185 & 2800 & 390 & 12.7 & 140 & 37,600 & 144 \\
\hline Lettuce & 333 & 1370 & 12,280 & 59,633 & 21.0 & 1191 & 14,500 & 1833 & 73.0 & 140 & 63,500 & 693 \\
\hline Tomato & 873 & $\overline{53.5}$ & 9100 & 1145 & 4.27 & 377 & 600 & 455 & 8.95 & 140 & 34,900 & $\overline{20.0}$ \\
\hline Onion & $\overline{816}$ & 113 & 8660 & 3370 & 8.00 & 1650 & 1300 & 600 & 10.9 & 140 & 72,200 & 203 \\
\hline Wheat & 42.2 & 45.8 & 6840 & 3120 & $3.54^{\mathrm{a}}$ & 617 & 1700 & 40.0 & 0.20 & 200 & 57,000 & 12.0 \\
\hline Parsley (leaf) & 118 & 843 & 13,300 & 22,100 & 26.0 & 6460 & 7300 & 1220 & 48.6 & 140 & 65,800 & 529 \\
\hline Quince & 173 & 177 & 7470 & 14,700 & $\overline{3.54^{\mathrm{a}}}$ & $\overline{218}$ & 5100 & 3310 & 12.3 & 140 & 24,300 & 76.0 \\
\hline Maize & 11.7 & 44.3 & 3420 & 3550 & $3.54^{\mathrm{a}}$ & 319 & 1700 & 70.0 & 1.50 & 140 & 30,500 & $3.54^{\mathrm{a}}$ \\
\hline Black maize & 5.40 & 13.0 & 2000 & 820 & $3.54^{\mathrm{a}}$ & 266 & 1000 & 10.0 & 4.90 & 140 & 36,600 & $3.54^{\mathrm{a}}$ \\
\hline Pumpkin seed & 211 & 433 & 21,700 & 25,800 & $3.54^{\mathrm{a}}$ & 575 & 10,600 & 40.0 & 2.30 & 300 & 62,100 & 42.0 \\
\hline Poppy seed & 158 & 98.4 & $\overline{20,900}$ & 170 & 5.00 & 955 & 2200 & 20.0 & $0.14^{\mathrm{a}}$ & $\overline{140}$ & 78,700 & 15.0 \\
\hline Propolis & 64.4 & 658 & 4570 & 4880 & $3.54^{\mathrm{a}}$ & 407 & 3100 & 11,100 & 181 & 140 & 102,000 & 183 \\
\hline Pollen & 129 & 68.9 & 10,590 & 1233 & $3.54^{\mathrm{a}}$ & 162 & 2000 & $\overline{93.3}$ & $\overline{4.63}$ & 140 & $\overline{55,600}$ & 29.0 \\
\hline${ }^{\mathrm{b}}$ Max allowable limit (depends & & & & & & & & & & & & \\
\hline on vegetable type) & $50-200$ & $2-20$ & 100 & $10,000-20,000$ & 30 & / & Toxic at any level & $100-300$ & / & / & $200-300$ & 500 \\
\hline
\end{tabular}

Underlined values indicate maximum measured values.

a Values under DL were replaced with $\operatorname{LOD} \sqrt{2}$.

b Maximum allowable limit of heavy metals in fish adopted by different health organisations. 


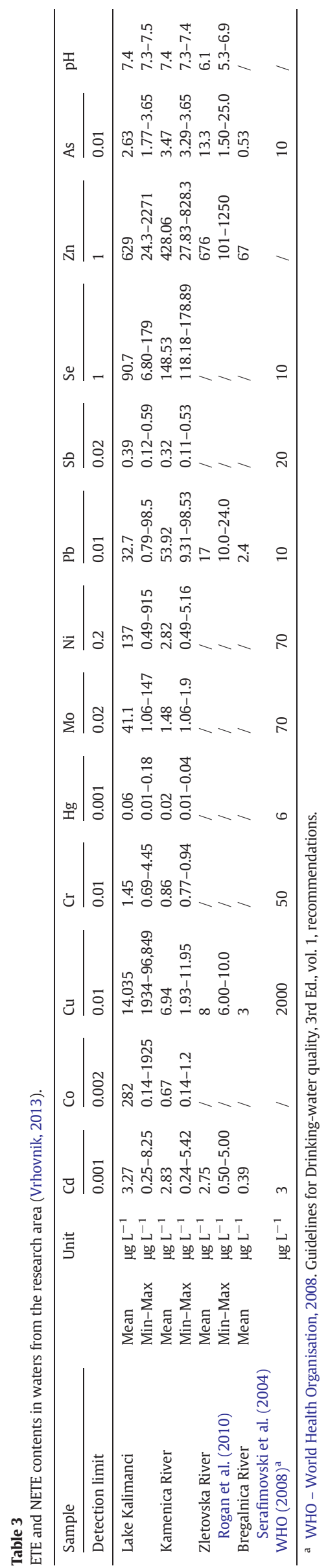

(Kalfakakour and Akrida-Demertzi, 2000; Rashed, 2001). This provided information of element content in edible crops The TF was given as:

$T F=\frac{\text { concentrationof } \frac{E T E}{N E T E} \text { inediblecrop }}{\text { concentrationof } \frac{E T E}{N E T E} \text { inecosystem }(\text { waterorsoil) }}$

Kalfakakour and Akrida-Demertzi (2000) and Rashed (2001) reported that fauna and flora undergo the bioaccumulation of trace elements from the environment in cases when TF is higher than 1.

To calculate TF relations also ETE and NETE concentrations in water were added to present study. Some of those were previously published in Vrhovnik et al., 2013a, 2013b, 2013c, 2013d, the rest were added. A summary of the levels of ETE and NETE found in water is presented in Table 3. Values detected in waters from the Makedonska Kamenica area (Lake Kalimanci and River Kamenica), compared to those from Kočani Field (River Bregalnica and Zletovska River) show that the former possess higher levels of ETE and NETE than those from Kočani region. Furthermore, if the measured contents of ETE and NETE are correlated with the Drinking Water Quality Guidelines adopted by WHO (2008), there are three elements which stand out from the others. These are $\mathrm{Pb}, \mathrm{Cd}$ and Se, which greatly exceed maximum allowable levels. Information about the ETE and NETE contents in water from surrounding rivers and lakes indicates that home-grown foodstuffs can contain elevated concentrations due to irrigation with contaminated water.

The calculated TF values in the relation of vegetables to water showed that the majority of the studied vegetables have much higher TF than 1, with exception of $\mathrm{Hg}$, Ni, Se and $\mathrm{Zn}$ which have TF below 1. The calculated TF sequence follows in the order: $\mathrm{Cr}>\mathrm{Mo}>\mathrm{Cu}>\mathrm{Co}>\mathrm{Sb}>\mathrm{As}>\mathrm{Cd}>\mathrm{Pb}>\mathrm{Hg}, \mathrm{Ni}>\mathrm{Se}, \mathrm{Zn}$. Much the same results were obtained after applying TF in relation to vegetables in Kočani soils, where $\mathrm{Ni}$ and $\mathrm{Zn}$ again had values below 1 , and the TF sequence was as follows: $\mathrm{Mo}>\mathrm{Cr}>\mathrm{Cd}>\mathrm{Cu}>\mathrm{Hg}>$ $\mathrm{Sb}>\mathrm{Pb}>\mathrm{Co}>\mathrm{As}$ (Se was excluded because it was not measured in the soil samples).

Table 4

EDI and EWI values in the study population.

\begin{tabular}{|c|c|c|c|c|c|c|c|}
\hline & & \multirow[t]{2}{*}{ Mean } & \multirow[t]{2}{*}{ Median } & \multirow{2}{*}{$\begin{array}{l}\text { Std. } \\
\text { deviation }\end{array}$} & \multirow[t]{2}{*}{ 25th } & \multicolumn{2}{|c|}{ Percentiles } \\
\hline & & & & & & 50th & 75th \\
\hline \multirow[t]{13}{*}{ EDI [mg] } & $\mathrm{Cd}$ & 0.00087 & 0.00082 & 0.00029 & 0.00073 & 0.00082 & 0.00097 \\
\hline & Co & 0.00063 & 0.00057 & 0.00031 & 0.00046 & 0.00057 & 0.00079 \\
\hline & $\mathrm{Cu}$ & 0.01450 & 0.01374 & 0.00579 & 0.01164 & 0.01374 & 0.01623 \\
\hline & $\mathrm{Cr}$ & 0.02030 & 0.01716 & 0.01146 & 0.01331 & 0.01716 & 0.02512 \\
\hline & $\mathrm{Hg}$ & 0.00030 & 0.00002 & 0.00229 & 0.00002 & 0.00002 & 0.00002 \\
\hline & Mo & 0.00159 & 0.00156 & 0.00060 & 0.00134 & 0.00156 & 0.00189 \\
\hline & $\mathrm{Ni}$ & 0.00615 & 0.00545 & 0.00312 & 0.00441 & 0.00545 & 0.00751 \\
\hline & $\mathrm{Pb}$ & 0.00139 & 0.00124 & 0.00076 & 0.00107 & 0.00124 & 0.00161 \\
\hline & Sb & 0.00006 & 0.00004 & 0.00016 & 0.00003 & 0.00004 & 0.00005 \\
\hline & Se & 0.00032 & 0.00031 & 0.00011 & 0.00026 & 0.00031 & 0.00036 \\
\hline & $\mathrm{Zn}$ & 0.07778 & 0.07591 & 0.02967 & 0.06357 & 0.07591 & 0.09024 \\
\hline & As & 0.00158 & 0.00034 & 0.00980 & 0.00029 & 0.00034 & 0.00046 \\
\hline & Total & 0.12547 & 0.11820 & 0.04801 & 0.10239 & 0.11820 & 0.14377 \\
\hline \multirow[t]{13}{*}{ EWI [mg] } & Cd & 0.00612 & 0.00537 & 0.00342 & 0.00351 & 0.00537 & 0.00826 \\
\hline & Co & 0.00350 & 0.00287 & 0.00263 & 0.00192 & 0.00287 & 0.00434 \\
\hline & $\mathrm{Cu}$ & 0.09464 & 0.08655 & 0.05427 & 0.05802 & 0.08655 & 0.12165 \\
\hline & $\mathrm{Cr}$ & 0.10924 & 0.07973 & 0.09842 & 0.05520 & 0.07973 & 0.13003 \\
\hline & $\mathrm{Hg}$ & 0.00088 & 0.00010 & 0.00627 & 0.00006 & 0.00010 & 0.00014 \\
\hline & Mo & 0.00931 & 0.00841 & 0.00565 & 0.00554 & 0.00841 & 0.01173 \\
\hline & $\mathrm{Ni}$ & 0.03398 & 0.02800 & 0.02692 & 0.01850 & 0.02800 & 0.04238 \\
\hline & $\mathbf{P b}$ & 0.00817 & 0.00747 & 0.00502 & 0.00468 & 0.00747 & 0.01024 \\
\hline & $\mathbf{S b}$ & 0.00032 & 0.00020 & 0.00075 & 0.00013 & 0.00020 & 0.00030 \\
\hline & Se & 0.00190 & 0.00172 & 0.00110 & 0.00112 & 0.00172 & 0.00242 \\
\hline & $\mathrm{Zn}$ & 0.48615 & 0.42806 & 0.28135 & 0.28432 & 0.42806 & 0.61906 \\
\hline & As & 0.00829 & 0.00197 & 0.05008 & 0.00126 & 0.00197 & 0.00253 \\
\hline & Total & 0.76251 & 0.67408 & 0.44869 & 0.46143 & 0.67408 & 0.95947 \\
\hline
\end{tabular}




\subsection{Levels and predictors of EDI/EWI in the study population}

A description of the estimated EDI and EWI values for the study population is shown in Table 4. The highest median EDIs were found for $\mathrm{Zn}(0.07591 \mathrm{mg})$ followed by $\mathrm{Cr}(0.01716 \mathrm{mg})$, while $\mathrm{Hg}$ showed the lowest values $(0.00002 \mathrm{mg})$ followed by $\mathrm{Sb}$ (0.00004 mg).

The results of the multivariable linear regression models for the predictors of EDI values in the study population are shown in Table 5 . We found a borderline-significant positive association between age and EDIs for Cd $(p=0.064)$, and a negative association for $\mathrm{Hg}(p=0.053)$ and $\mathrm{Sb}(p=0.054)$. The lower intake of $\mathrm{Hg}$ and $\mathrm{Sb}$ for older individuals could be correlated with only a minor intake of certain foodstuffs containing $\mathrm{Hg}$ and Sb. Furthermore, BMI was negatively associated with total EDI $(p=0.026)$, which was also statistically significant for individual EDIs of $\mathrm{Cd}, \mathrm{Cu}, \mathrm{Mo}, \mathrm{Ni}, \mathrm{Se}, \mathrm{Zn}$; and borderline-significant for $\mathrm{Co}$ and $\mathrm{Cr}$. Given that trace element exposure was calculated using dietary habits, this inverse association might be due to a reversed-causality, given that obese people might be on weight-reducing regimes, and therefore have a lower intake of trace elements at the moment of recruitment. In comparison to women, men showed statistically significant lower total EDI levels $(p=0.023)$, and a similar significant association was also found for most individual EDIs ( $\mathrm{Cd}, \mathrm{Co}, \mathrm{Cu}, \mathrm{Cr}, \mathrm{Mo}, \mathrm{Ni}, \mathrm{Se}$, and $\mathrm{Zn}$ ). We did not find any statistically significant association of EDIs with ethnicity or occupation.

\section{Conclusions}

The greatest direct benefit of different earth materials to public health is that surficial soils provide a unique source for food production, either directly consumed by humans or indirectly consumed via livestock. Thus, in both cases, plant nutrition is the result of soil characteristics (e.g. ETE, NETE contents) that ultimately affect human, as well as animal, health and welfare. Both ETE and NETE are naturally present in soils; however, in the present study we show increased concentrations of these elements as a result of anthropogenic inputs, especially related with mining activity and related industry. Not only the background geological composition but also the closeness of unprotected tailing dams additionally increase the atmospheric deposition of trace elements on widespread agricultural areas. In addition, regular irrigation with contaminated waters should not be neglected when evaluating possible reasons for such heavily contaminated foodstuffs.

The present study represents one of the very first attempts to estimate human dietary exposure to ETE and NETE and its predictors in the study region. We identified a set of specific food items that might be important contributors to the exposure to each chemical, as well as certain population subgroups that might be particularly exposed (e.g., women, young people). Exposure assessment to environmental pollutants in developing countries is crucial, given that they might show different patterns of exposure because of specific dietary/lifestyle patterns or inadequate regulations (El Sebae, 1993; Arrebola

Table 5

Predictors of trace element EDIs. Multivariable linear regression analyses.

\begin{tabular}{|c|c|c|c|c|c|c|c|}
\hline & & Age (years) & Sex (=male $)$ & Ethnic group (= Macedonian) & Farmer & Industry/mining & BMI $\left(\mathrm{Kg} / \mathrm{m}^{2}\right)$ \\
\hline \multirow{3}{*}{$\mathrm{Cd}$} & Beta & 0.48 & -16.91 & -4.49 & -0.58 & 3.96 & -3.08 \\
\hline & SE & 0.25 & 7.94 & 12.04 & 8.98 & 10.89 & 1.05 \\
\hline & $\mathrm{p}$ & 0.064 & 0.037 & 0.710 & 0.949 & 0.717 & $<0.001$ \\
\hline \multirow{3}{*}{ Co } & Beta & -0.13 & -17.64 & 2.51 & -0.03 & -0.16 & -1.92 \\
\hline & $\mathrm{SE}$ & 0.27 & 8.31 & 12.59 & 9.39 & 11.40 & 1.10 \\
\hline & $\mathrm{p}$ & 0.617 & 0.038 & 0.843 & 0.997 & 0.989 & 0.087 \\
\hline \multirow{3}{*}{$\mathrm{Cu}$} & Beta & 5.61 & -365.00 & -45.17 & -70.54 & 29.41 & -57.00 \\
\hline & SE & 4.91 & 153.82 & 233.17 & 173.87 & 211.02 & 20.36 \\
\hline & $\mathrm{p}$ & 0.258 & 0.021 & 0.847 & 0.686 & 0.890 & 0.007 \\
\hline \multirow{4}{*}{$\mathrm{Cr}$} & Beta & -3.87 & -650.53 & 17.99 & -175.05 & 8.44 & -75.26 \\
\hline & SE & 9.83 & 308.24 & 467.26 & 348.42 & 422.86 & 40.81 \\
\hline & $\mathrm{p}$ & 0.696 & 0.039 & 0.969 & 0.617 & 0.984 & 0.070 \\
\hline & Beta & -4.21 & 37.29 & 64.87 & 126.15 & -10.23 & 11.40 \\
\hline \multirow[t]{3}{*}{$\mathrm{Hg}$} & SE & 2.13 & 66.63 & 101.00 & 75.31 & 91.40 & 8.82 \\
\hline & $\mathrm{p}$ & 0.053 & 0.578 & 0.523 & 0.099 & 0.911 & 0.201 \\
\hline & Beta & 0.83 & -40.09 & -3.63 & -3.59 & 2.95 & -5.65 \\
\hline \multirow[t]{3}{*}{ Mo } & SE & 0.52 & 16.30 & 24.71 & 18.43 & 22.37 & 2.16 \\
\hline & $\mathrm{p}$ & 0.116 & 0.017 & 0.884 & 0.846 & 0.896 & 0.011 \\
\hline & Beta & 0.26 & -191.08 & -2.74 & -54.58 & 4.04 & -23.65 \\
\hline \multirow[t]{3}{*}{$\mathrm{Ni}$} & $\mathrm{SE}$ & 24,139 & 83.29 & 126.25 & 94.14 & 114.26 & 11.03 \\
\hline & $\mathrm{p}$ & 0.923 & 0.025 & 0.983 & 0.564 & 0.972 & 0.036 \\
\hline & Beta & -0.77 & -22.74 & 17.69 & 29.40 & -0.94 & -1.24 \\
\hline \multirow[t]{3}{*}{$\mathrm{Pb}$} & SE & 0.71 & 22.24 & 33.71 & 25.14 & 30.51 & 2.94 \\
\hline & $\mathrm{p}$ & 0.282 & 0.311 & 0.602 & 0.247 & 0.975 & 0.675 \\
\hline & Beta & -0.29 & 1.53 & 4.53 & 8.72 & -0.67 & 0.66 \\
\hline \multirow[t]{3}{*}{$\mathrm{Sb}$} & SE & 0.15 & 4.68 & 7.09 & 5.29 & 6.42 & 0.62 \\
\hline & $\mathrm{p}$ & 0.054 & 0.744 & 0.525 & 0.105 & 0.917 & 0.290 \\
\hline & Beta & 0.14 & -7.77 & -1.81 & 0.87 & 1.15 & -1.22 \\
\hline \multirow[t]{3}{*}{ Se } & SE & 0.09 & 2.91 & 4.42 & 3.29 & 4.00 & 0.39 \\
\hline & $\mathrm{p}$ & 0.142 & 0.010 & 0.683 & 0.792 & 0.775 & $<0.001$ \\
\hline & Beta & 39.89 & -1915.67 & -190.16 & -361.46 & 153.37 & -284.47 \\
\hline \multirow[t]{3}{*}{$\mathrm{Zn}$} & $\mathrm{SE}$ & 25.46 & 798.15 & 1209.89 & 902.19 & 1094.94 & 105.66 \\
\hline & $\mathrm{p}$ & 0.123 & 0.020 & 0.876 & 0.690 & 0.889 & 0.009 \\
\hline & Beta & -17.94 & 151.40 & 279.12 & 536.85 & -44.25 & 47.88 \\
\hline \multirow[t]{3}{*}{ As } & $\mathrm{SE}$ & 9.09 & 284.96 & 431.97 & 322.11 & 390.93 & 37.72 \\
\hline & $\mathrm{p}$ & 0.053 & 0.597 & 0.521 & 0.101 & 0.910 & 0.209 \\
\hline & Beta & 2.00 & -303.72 & 13.87 & 3.62 & 14.71 & -39.35 \\
\hline \multirow[t]{2}{*}{ Total } & $\mathrm{SE}$ & 4.15 & 130.14 & 197.28 & 147.11 & 178.53 & 17.23 \\
\hline & $\mathrm{p}$ & 0.632 & 0.023 & 0.944 & 0.980 & 0.935 & 0.026 \\
\hline
\end{tabular}

SE: Standard deviation; in order to assess the interpretation of the coefficients, dependent variables were entered multiplied by 10,000 . 
et al., 2012). Further studies are warranted on the assessment of potential health implications of this exposure.

\section{Acknowledgements}

We thank Dr. Elaine Mutch and Dr. Tadej Dolenec for their invaluable support with this project.

During this work, Dr JP Arrebola was first under a postdoctoral contract from the Junta de Andalucía, Spain (RH-0092-20013), and later under contract from the Instituto de Salud Carlos III, Spain (Miguel Servet Program CP15/00193).

This study was financially supported by the ARRS Programme group P1-0195 (Geochemical and structural processes).

\section{References}

Alam, M.G.M., Snow, E.T., Tanaka, A., 2003. Arsenic and heavy metal contamination of vegetables grown in Samta village, Bangladesh. Sci. Total Environ. 308, 83-96.

Ali, M.H.H., Al-Qahtani, K.M., 2012. Assessment of some heavy metals in vegetables, cereals and fruits in Saudi Arabian markets. Egypt. J. Aquat. Res. 38, 31-37.

Amin, N., Hussain, A., Alamzeb, S., Begum, S., 2013. Accumulation of heavy metals in edible parts of vegetables irrigated with waste water and their daily intake to adults and children, District Mardan, Pakistan. Food Chem. 136, 1515-1523.

Arrebola, J.P., Cuellar, M., Claure, E., Quevedo, M., Antelo, S.R., Mutch, E., Ramirez, E., Fernandez, M.F., Olea, N., Mercado, L.A., 2012. Concentrations of organochlorine pesticides and polychlorinated biphenyls in human serum and adipose tissue from Bolivia. Environ. Res. 112, 40-47. http://dx.doi.org/10.1016/j.envres.2011.10.006.

Chung, B.Y., Song, C.H., Park, B.J., Cho, J.Y., 2011. Heavy metals in brown rice (Oryza sativa L.) and soil after long-term irrigation of wastewater discharged from domestic sewage treatment plants. Pedosphere 21 (5), 621-627.

CIA - Central Intelligence Agency - The World Factbook, 2001. Available on line: https:// www.cia.gov/library/publications/the-world-factbook/geos/mk.html (Accessed: 15.11.2012).

Dolenec, T., Serafimovski, T., Tasev, G., Dobnikar, M., Dolenec, M., Rogan, N., 2007. Major and trace elements in paddy soil contaminated by Pb-Zn mining: a case study of Kočani Field, Macedonia. Environ. Geochem. Health 29, 21-32.

EC, 2001. Commission regulation (EC) 466/2001. Setting maximum levels for certain foodstuffs. Off. J. Eur. Communities 77.

El Sebae, A.H., 1993. Special problem experienced with pesticide use in developing countries. Regul. Toxicol. Pharmacol. 17, 287-291.

Fox, J., 2008. Applied regression analysis and generalized linear models. Sage Publications, California.

Horvath, B., Gruiz, K., 1996. Impact of metalliferous ore mining activity on the environment in Gyongyosorozi, Hungary. Sci. Total Environ. 184, 215-227.

Hu, X., Zheng, T., Cheng, Y., Holford, T., Lin, S., Leaderer, B., Qiu, J., Bassig, B.A., Shi, K. Zhang, Y., Niu, J., Zhu, Y., Li, Y., Guo, H., Chen, Q., Zhang, J., Xu, S., Jin, Y., 2015. Distributions of heavy metals in maternal and cord blood and the association with infant birth weight in China. J. Reprod. Med. 60 (1-2), 21-29.

Itanna, F., 2002. Metals in leafy vegetables grown in Addis Ababa and toxicological implications. Ethiop. J. Heal. Dev. 6, 295-302.

Kalfakakour, V., Akrida-Demertzi, K., 2000. Transfer Factors of Heavy Metals in Aquatic Organisms of Different Trophic Levels. Vol. 1. HTML Publications, pp. 768-778.

Lake, D.L., Kirk, P.W.W., Lester, J.N., 1984. The fractionation, characterization and speciation of heavy metals in sewage sludge and sewage sludge amended soils: a review. J. Environ. Qual. 13, 175-183.

Madyiwa, S., Chimbari, M., Nyamangara, J., Bangira, C., 2002. Cumulative effects of sewage sludge and effluent mixture application on soil properties of a sandy soil under a mixture of star and kikuyu grasses in Zimbabwe. Phys. Chem. Earth A/B/C 27, 747-753.

Mapanda, F., Mangwayana, E.N., Nyamangara, J., Giller, K.E., 2005. The effect of long-term irrigation using wastewater on heavy metal contents of soils under vegetables in Harare, Zimbabwe. Agric. Ecosyst. Environ. 107 (2), 151-165.
Nabulo, G., Young, S.D., Black, C.R., 2010. Assessing risk to human health from tropical leafy vegetables grown on contaminated urban soils. Sci. Total Environ. 408, 5338-5351

Ning, L., Yuan, K., Weijian, P., Qiuyun, Z., Jiwen, L., 2015. Concentration and transportation of heavy metals in vegetables and risk assessment of human exposure to bioaccessible heavy metals in soil near a waste-incinerator site, South China. Sci. Total Environ. 521-522, 144-151.

Orton, F., Ermler, S., Kugathas, S., Rosivatz, E., Scholze, M., Kortenkamp, A., 2013. Mixture effects at very low doses with combinations of anti-androgenic pesticides, antioxidants, industrial pollutant and chemicals used in personal care products. Toxicol. Appl. Pharmacol. 278 (3), 201-208. http://dx.doi.org/10.1016/j.taap.2013.09.008.

Oyoo-Okoth, E., Admiraal, W., Osano, O., Ngure, V., Kraak, M.H.S., Omutange, E.S., 2010. Monitoring exposure to heavy metals among children in Lake Victoria, Kenya: environmental and fish matrix. Ecotoxicol. Environ. Saf. 73, 1797-1803.

Ramirez-Andreotta, M.D., Brusseau, M.L, Artiola, J.F. Maier, R.M. 2013. A greenhouse and field-based study to determine the accumulation of arsenic in common homegrown vegetables grown in mining-affected soils. Sci. Total Environ. 443, 299-306.

Rashed, M.N., 2001. Monitoring of environmental heavy metals in fish from Nasser Lake. Environ. Int. 27, 27-33.

Rogan, N., Dolenec, T., Serafimovski, T., Tasev, G., Dolenec, M., 2010. Distribution and mobility of heavy metals in paddy soils of the Kočani Field in Macedonia. Environ. Earth Sci. 61 (5), 899-907.

Serafimovski, T., Alderton, D.H.M., Mullen, B., Fairall, K., 2004. Pollution associated with metal mining in Macedonia. $23^{\text {nd }}$ International Geological Congress, FL.

Simovska-Jarevska, V., Damjanovski, D., Pavlova, V., Martionvski, S., Vidin, M., 2012. Evaluation of dietary habits and physical activity level monitoring as basis for a new health promotion strategy in Republic of Macedonia. Proc. Soc. Behav. Sci. 44, 370-374.

Swaddiwudhipong, W., Mahasakpan, P., Jeekeeree, W., Funkhiew, T., Sanjum, R., Apiwatpaiboon, T., Phopueng, I., 2014. Renal and blood pressure effects from environmental cadmium exposure in Thai children. Environ. Res. 136, 82-87. http://dx.doi. org/10.1016/j.envres.2014.10.017.

Thomas, S., Arbuckle, T.E., Fisher, M., Fraser, W.D., Ettinger, A., King, W., 2015. Metals exposure and risk of small-for-gestational age birth in a Canadian birth cohort: the MIREC study. Environ. Res. 140, 430-439. http://dx.doi.org/10.1016/j.envres.2015. 04.018

Turkdogan, M.K., Kilicel, F., Kara, K., Tuncer, I., 2002. Heavy metals in soil, vegetables and fruits in the endemic upper gastrointestinal cancer region of Turkey. Environ. Toxicol. Pharmacol. 13, 175-179.

U.S. Env.Prot.Agency (USEPA), 2002. Region 9, preliminary remediation goals available at: http://www.epa.gov/region09/waste/sfund/prg.

Votusa, D., Grimanis, A., Samara, C., 1996. Trace elements in vegetables grown in industrial areas in relation to soil and air particulate matter. Environ. Pollut. 94, 325-335.

Vrhovnik, P., 2013. Assessment of Lake Environment: Relevance to Human Exposure. LAP Lambert Academic Publishing, Saarbrücken, p. 156.

Vrhovnik, P., Arrebola, J.P., Serafimovski, T., Dolenec, T., Rogan Šmuc, N., Dolenec, M., Mutch, E., 2013d. Potentially toxic contamination of sediments, water and two animal species in Lake Kalimanci, FYR Macedonia: relevance to human health. Environ. Pollut. 180, 92-100.

Vrhovnik, P., Dolenec, T., Serafimovski, T., Dolenec, M., Rogan Šmuc, N., 2013b. The occurrence of heavy metals and metalloids in surficial lake sediments before and after a tailings dam failure. Pol. J. Environ. Stud. 2 (5), 1525-1538.

Vrhovnik, P., Rogan Šmuc, N., Dolenec, T., Serafimovski, T., Dolenec, M., 2013a. An evaluation of trace metal distribution and environmental risk in sediments from the Lake Kalminaci (FYR Macedonia). Environ. Earth Sci. 70, 761-775.

Vrhovnik, P., Rogan Šmuc, N., Dolenec, T., Serafimovski, T., Dolenec, M., 2013c. Impact of $\mathrm{Pb}-\mathrm{Zn}$ mining activity on surficial sediments of Lake Kalimanci (FYR Macedonia). Turk. J. Earth Sci. 22, 996-1009. http://dx.doi.org/10.3906/yer-1205-1.

WHO - World Health Organisation, 1996. Trace elements in human nutrition and health Geneva.

WHO - World Health Organisation, 2008. Guidelines for Drinking-water Quality. third ed. Recommendations vol. 1.

Xilong, W., Sato, T., Baoshan, X., Tao, S., 2005. Health risks of heavy metals to the general public in Tianjin, China via consumption of vegetables and fish. Sci. Total Environ. $350,28-37$. 